\title{
What Process Optimizes Convective Drying of Farm Products with Complex Constitution: Case of Okra (Abelmoschus esculentus)
}

\author{
Ouoba Kondia Honoré ${ }^{*}$, Desmorieux Hélène ${ }^{2}$, Zougmore François ${ }^{1}$ \\ ${ }^{1}$ Laboratoire des Matériaux et Environnement (LA.M.E.), Ecole Doctorale Sciences et Technologies (EDST), Université Ouaga I Pr \\ Joseph KI-ZERBO, Ouagadougou, Burkina Faso \\ ${ }^{2}$ Laboratoire d'Automatique et de Génie des Procédés (LAGEP), UMR CNRS 5007, Université Claude Bernard Lyon 1-CPE-Bat, \\ Lyon, France \\ Email: *ouobakahonore@yahoo.fr, *ouoba@lagep.univ-lyon 1.fr
}

How to cite this paper: Honoré, O.K., Hélène, D. and François, Z. (2019) What Process Optimizes Convective Drying of Farm Products with Complex Constitution: Case of Okra (Abelmoschus esculentus). Journal of Agricultural Chemistry and Environment, 8, 14-22.

https://doi.org/10.4236/jacen.2019.81002

Received: November 20, 2018

Accepted: December 21, 2018

Published: December 24, 2018

Copyright $\odot 2019$ by authors and Scientific Research Publishing Inc. This work is licensed under the Creative Commons Attribution International License (CC BY 4.0).

http://creativecommons.org/licenses/by/4.0/

(c) (i) Open Access

\begin{abstract}
In this paper, we propose an optimized process for farm product convective drying. Above and beyond the influence of the air parameters on foodstuff convective drying, this work shows that product internal parameters and drying proceedings must be taken into account during the evaluation of their convective drying. Results indicate that okra maturity influences its convective drying. It dries faster when it is too young or when it is advanced age. Drying time of okra of 1,2, 3, 4 and 5 days old is respectively $580 \mathrm{~min}, 780 \mathrm{~min}, 990 \mathrm{~min}, 1200 \mathrm{~min}$ and $850 \mathrm{~min}$. Also, one observes that considering okra on its three zones according it length, i.e. its base, middle and extremity parts have not the same resistance to transfers during convective drying. These three zones have respectively 400 min, $520 \mathrm{~min}$ and $600 \mathrm{~min}$ of drying time. Okra cut reveals a major importance on its convective drying evaluation. The longitudinal cut dividing okra on four parts, sliced with $5 \mathrm{~mm}$ and $10 \mathrm{~mm}$ of thickness and the whole okra put respectively $150 \mathrm{~min}, 200 \mathrm{~min}, 280 \mathrm{~min}$ and $400 \mathrm{~min}$ for their drying. At last, three (03) different constituents of okra, namely, the skin, the seeds and central material behave differently during convective drying. The drying time of the central material, the seeds and the skin is about $70 \mathrm{~min}, 150 \mathrm{~min}$ and $190 \mathrm{~min}$ respectively, against $400 \mathrm{~min}$ for the whole okra.
\end{abstract}

\section{Keywords}

Okra Convective Drying, Maturity, Constituents, Form Cut 


\section{Introduction}

Farm products' drying is a subject of a great importance. It is an adequate means to ensure the overproduction conservation [1] [2] and for economic development [3]. For that comes true, the dried product has to suit consumer's expectations: gustative appreciation [4] and the dietary and medical domains [5].

It is known that air parameters such as temperature, velocity, the exposure time of the product have an important role on the dried product quality [6] [7]. Long exposure time and high temperature can destroy the fragile cellular structure and the volatile elements content such as aromas and vitamins.

In the present work, we look for processes which optimize the organic product drying. We examine the contribution of the various parameters intrinsic to the product nature. Also, we analyze product constituents, maturity and cut form influence on the convective drying, applied to the okra. We take into account the mechanical difference existing between the various parts of the okra. Considering all these processes, we propose the practice which optimizes the convective drying of organic products with complex constitution as the okra.

\section{Material and Method}

\subsection{0kra}

In this study, the okra (Abelmoschus esculentus) is considered as foodstuff product having complex constitution and structure. As shows in Figure 1 regarding okra longitudinal cut, we can bring out three different constituents. The skin with green-dark color forms the okra external envelope. Inside the vegetable we find more or less spherical seeds. These seeds are fixed on a spongy material which constitutes the okra central axis.

The cut on the okra reveals that seeds did not uniformly distributed throughout the vegetable. Okra seeds are dense at it middle and least at the extremities. Such distributions of seeds induce mechanical consequences [8]. Thus, okra has a firmer consistency at the center and is more flexible at the extremity. In this study, we divide the vegetable into three (03) zones [9]: the situated zone near the peduncle named "basis"; the center zone named "center"; and the zone situated at the extremity which is named "extremity" (Figure 1). We shall examine the behavior, during convective drying, of these zones having various contents in seeds and different mechanical properties.

During okra maturity process, the vegetable changes aspect, color and mechanical properties. The young okra is of green-dark color and breakable whereas advanced in age, it become tough, inflexible then stiff. Furthermore, the fibers content increase with okra age.

\subsection{Material and Treatment}

Okras used in the present work are obtained in a local market of Bobo-Dioulasso, Burkina Faso. Some of them were carried in France, wrapped with blotting paper and store in a refrigerator. We used a convective dryer in University Claude 


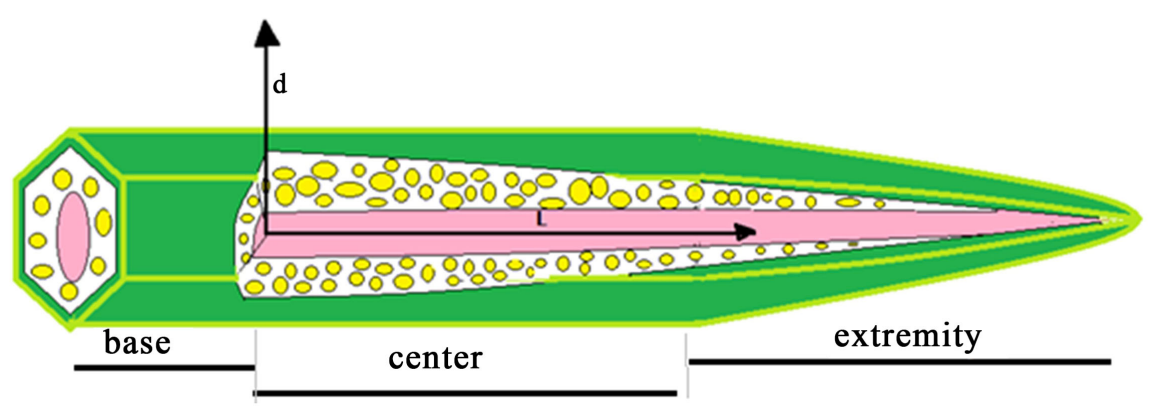

Figure $1 .{ }^{*}$ ) Okra constitution from outside to inside: skin, seeds and central material; ${ }^{\star *}$ ) Subdivision in three zones: base-center-extremity.

Bernard. This dryer described by Dissa et al. [10] records automatically the mass of the sample in the meantime settled by the experimentation. These results are used for $\mathrm{D}_{\text {eff }}$ determination.

Other okras were carried out in Polytechnic University of Bobo in GERME-TI. The okra is picked in the field at the fixed age, then transported in the laboratory where it was dried in the oven-dryer (WTF BINDER). We cut them in the sizes prefixed or cut in manner to isolate the various constituents for their drying. As for the influence of okra maturity, the experiments were carried out daily, from the farm to the laboratory.

\subsection{Drying Characterization}

\subsubsection{Moisture Content and Drying Kinetics Establishment}

Okra initial moisture content as well as its constituents is determined by the relation [9] (1):

$$
X_{0}=\frac{m_{e}}{m_{s}}=\frac{m_{0}-m_{s}}{m_{s}}
$$

where $m_{e}(\mathrm{Kg})$ is the mass of water initially contained in the product, $m_{0}(\mathrm{Kg})$ are the initial mass of the sample and $m_{s}$ the dried sample mass.

The moisture content at any time $\mathrm{t}$ during the drying process is $X(t)$ $\left(\mathrm{kg}_{\mathrm{e}} \cdot \mathrm{kg}^{-1}{ }_{\mathrm{ms}}\right)$ determined from the experimental data by the formula (2) [11]:

$$
X(t)=\frac{m(t)-m_{s}}{m_{s}}
$$

where $m(t)(\mathrm{Kg})$ is the mass of the sample at time $t(s)$ throughout the drying. The drying kinetics are fitted by the variation of $X(t)$ versus drying time.

\subsubsection{Diffusion Coefficient and Activation Energy}

For the diffusion coefficients determination, we consider whole okra having a cylindrical shape. The solutions of Fick's second law for the sample shape can be found by some assumptions [12] [13]: For that purpose, the experimental results can be analyzed by using the diffusion equation of Fick, developed by Crank on 1975 [14] [15] [16]. Supposing that transfers are one dimension direction, the moisture content initially uniform in the product, without contraction of the 
solid material and long time periods [17] [18], the analytical solution of Fick's equation is given by Equation (3) for the cylindrical shape [19]:

$$
M R=\frac{X_{t}-X_{e q}}{X_{0}-X_{e q}}=\frac{4}{\beta^{2}} \exp \left(-\frac{\beta^{2} D_{e f f} t}{r_{c}^{2}}\right)
$$

In this Equation (3), $M R$ is the moisture content ratio, $X_{t}\left(\mathrm{~kg}_{\mathrm{e}} \cdot \mathrm{kg}_{\mathrm{ms}}^{-1}\right)$ the average moisture content of the product, $X_{0}\left(\mathrm{~kg}_{\mathrm{e}} \cdot \mathrm{kg}^{-1}{ }_{\mathrm{ms}}\right)$ its initial moisture content, $X_{e q}\left(\mathrm{~kg}_{\mathrm{e}} \cdot \mathrm{kg}_{\mathrm{ms}}^{-1}\right)$ the moisture content at equilibrium, $D_{\text {eff }}\left(\mathrm{m}^{2} \cdot \mathrm{s}^{-1}\right)$ is the coefficient of effective diffusion, $r_{c}(\mathrm{~m})$ is the radius of the cylinder which represents the okra and $t(s)$ the drying time. The diffusion coefficient generally determined by plotting $\ln (M R)$ versus time $t$. Diffusion coefficient is determined by the slope of $\ln (M R)$ versus time. Indeed, Equation (3) [7] can be further simplified in Equation (4) [20] [21]:

$$
\ln (M R)=A-B \cdot t
$$

$A$ and $B$ are constants deduced graphically from the obtained straight line $\ln (M R)-t$; then the diffusion coefficient is calculated. Some authors have shown that $D_{\text {eff }}$ depends on the temperature. This dependence is linear according to the opposite of the temperature $1 / \mathrm{T}$ [6] [10] [22].

\section{Results and Discussions}

\subsection{Influence of Air Parameters}

The influence of the external parameters such as the drying air, velocity and temperature was widely studied foodstuffs' convective drying process. In this work, we examine the behavior of whole okra as well as its different constituents, taken separately, according to drying air temperature during its convective drying. We used drying air temperatures of $40^{\circ} \mathrm{C}, 50^{\circ} \mathrm{C}$ and $70^{\circ} \mathrm{C}$ for this purpose. In Figure 2, the results show that the temperature has an important role during the process of water and heat transfers in the product. The more temperature is high, the more transfers are easy and the drying is fast. The time necessary to reduce the moisture content from $5.04\left(\mathrm{Kg}_{\mathrm{e}} \cdot \mathrm{Kg}_{\mathrm{ms}}{ }^{-1}\right)$ to a final moisture content of $0.1\left(\mathrm{Kg}_{\mathrm{e}} \cdot \mathrm{Kg}_{\mathrm{ms}}{ }^{-1}\right)$ respectively for $40^{\circ} \mathrm{C}, 50^{\circ} \mathrm{C}$ and $70^{\circ} \mathrm{C}$ is of $900 \mathrm{~min}, 8000 \mathrm{~min}$ and $3000 \mathrm{~min}$. So, the whole okra dries fast 3.3 and 9 times at $70^{\circ} \mathrm{C}$ than $50^{\circ} \mathrm{C}$ and $40^{\circ} \mathrm{C}$ respectively. Furthermore it takes longer, 2.7 times to dry at $40^{\circ} \mathrm{C}$ than drying at temperature of $50^{\circ} \mathrm{C}$.

From the experimental data we determine the okra's diffusion coefficient. In Figure 3 the straight lines of $\ln (M R)$ versus $t$, are plotted for different temperatures. From there and by the mean of Equation (4), values of the constants are calculated. Then, we determined the diffusion coefficient, using Equation (3) and assuming that okra has a uniform shape, a cylindrical shape. Values of $D_{\text {eff }}$ are $1.02 .10^{-10} \mathrm{~m}^{2} \cdot \mathrm{s}^{-1}, 2.83 .10^{-10} \mathrm{~m}^{2} \cdot \mathrm{s}^{-1}$, and $5.85 .10^{-10} \mathrm{~m}^{2} \cdot \mathrm{s}^{-1}$ respectively at temperatures $40^{\circ} \mathrm{C}, 50^{\circ} \mathrm{C}$ and $70^{\circ} \mathrm{C}$ under a relative humidity of $\mathrm{HR}=30 \%$ and air velocity of $\mathrm{V}_{\text {air }}=1.5 \mathrm{~m} \cdot \mathrm{s}^{-1}$. The value of $\mathrm{D}_{\text {eff }}$ increases with the temperature. 


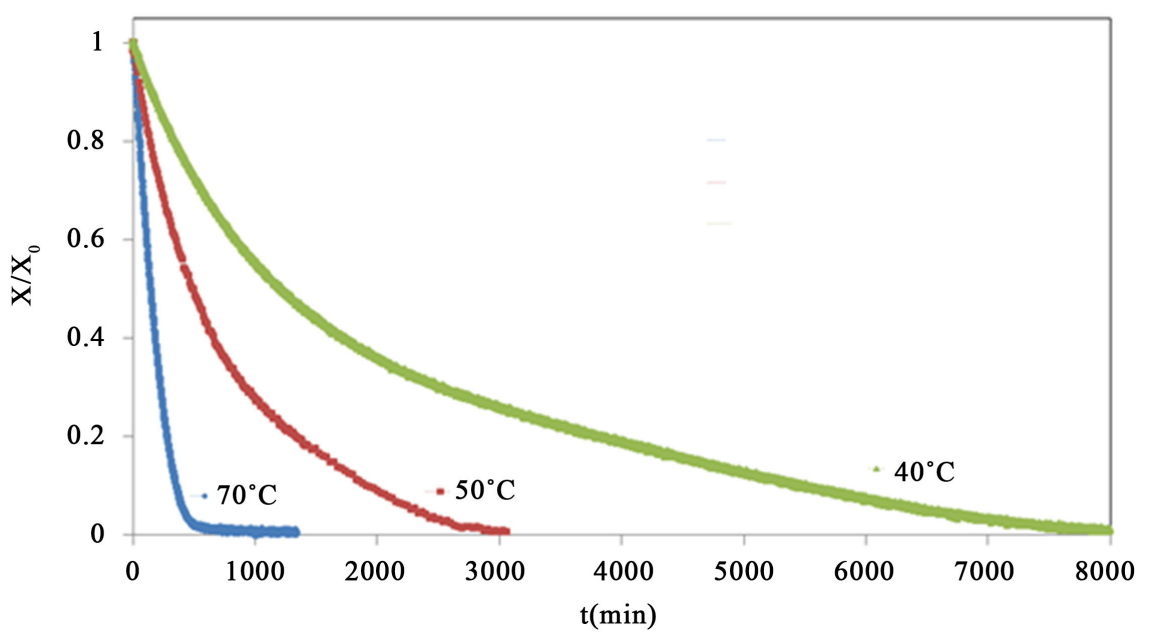

Figure 2. Air drying temperature influence on okra convective drying.

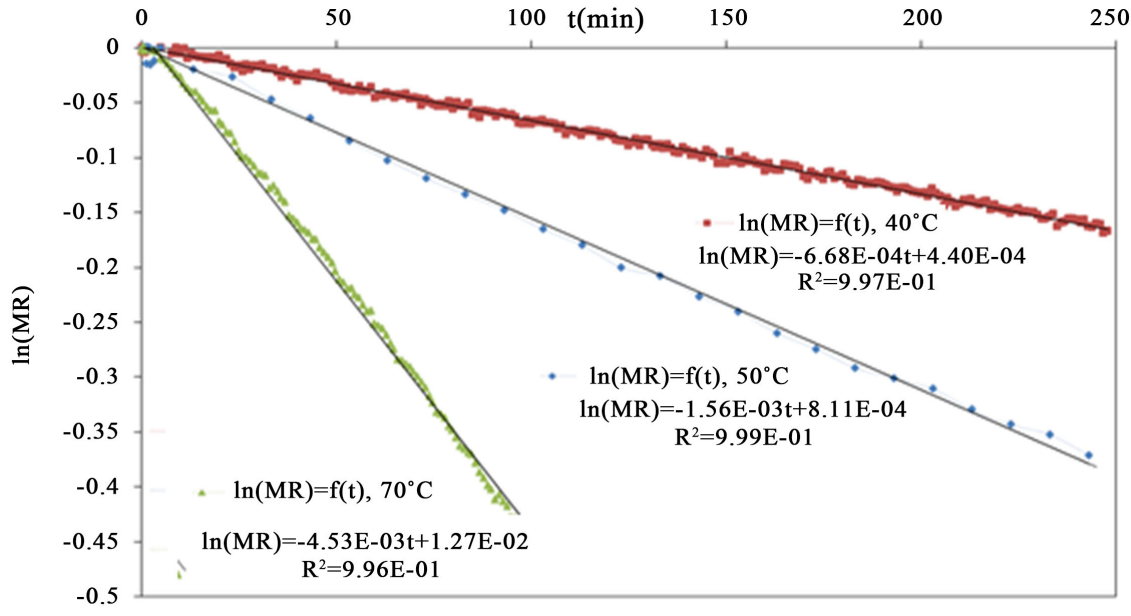

Figure 3. $\ln (\mathrm{MR})$ evolution with drying time for okra diffusion coefficient determination.

\subsection{Considering Okra Maturity}

In this work, the drying of the whole okra was studied by taking into account the vegetable's age, its maturity.

These results (Figure 4) can be explained by the evolution of okra moisture content during its process of maturity and the change of the mechanical characteristics which comes along. Indeed, the okra has high moisture content when it is young, and as it advances in age its moisture content decreases. In parallel, fibers content increases with its age, changing so its mechanical properties.

\subsection{Considering the Zone of Cut}

The mechanical change along okra seems to be an effect of its content in seed. This section deals with the influence of okra different zones on its convective drying. We examine the behavior difference of three zones cut along okra named base, central and extremity. Figure 5 shows that samples taken at the base, in the middle and at the end of the okra have no same resistance to transfers during its 
convective drying. These three zones have respectively $400 \mathrm{~min}, 520 \mathrm{~min}$ and 600 min of drying Time.

\subsection{Prise En Compte De La Composition Du Produit}

We dry each constituent of okra separately to examine their single behaviour during convective drying. The results as shown in Figure 6 indicated that these three (03) constituents of okra have not the same behaviour regarding mass and heat transfer during convective drying. The central material needs $70 \mathrm{~min}$ to dry, whereas the seeds and the skin take about $150 \mathrm{~min}$ and $190 \mathrm{~min}$ respectively. When we consider the whole okra, drying time is about $400 \mathrm{~min}$. One can conclude that okra's skin slow down considerably the transfer process.

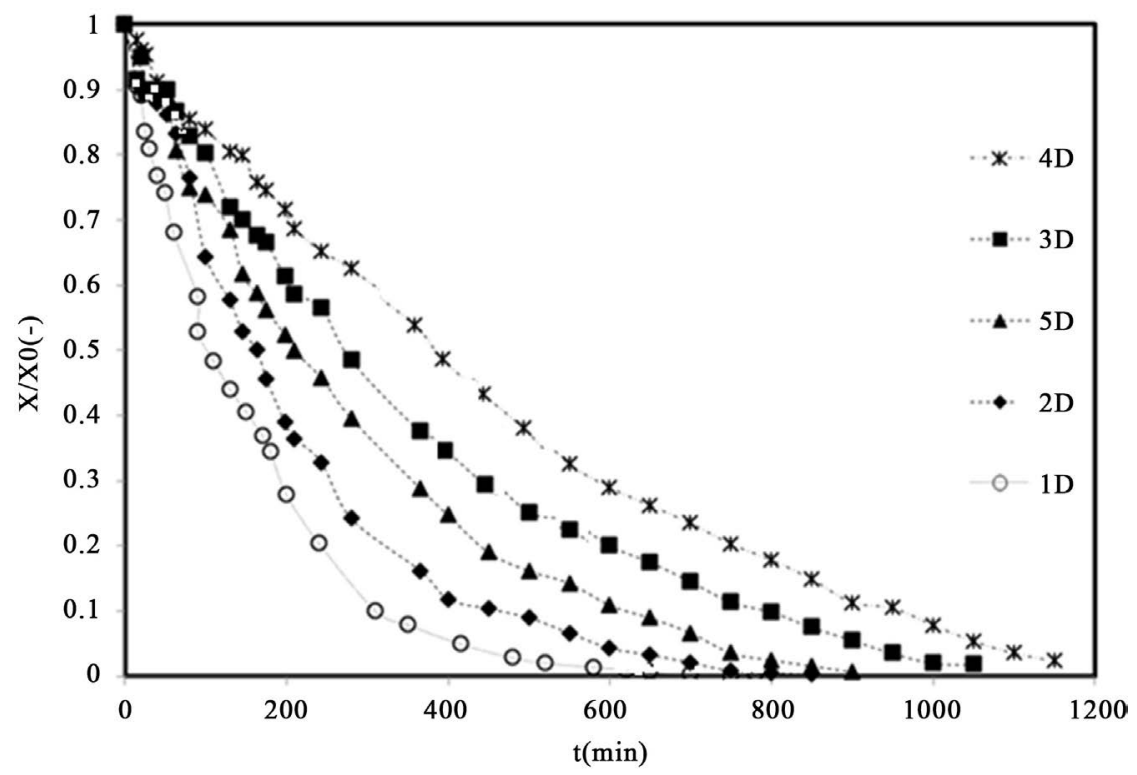

Figure 4. Maturity influence on okra convective drying; $70^{\circ} \mathrm{C}$.

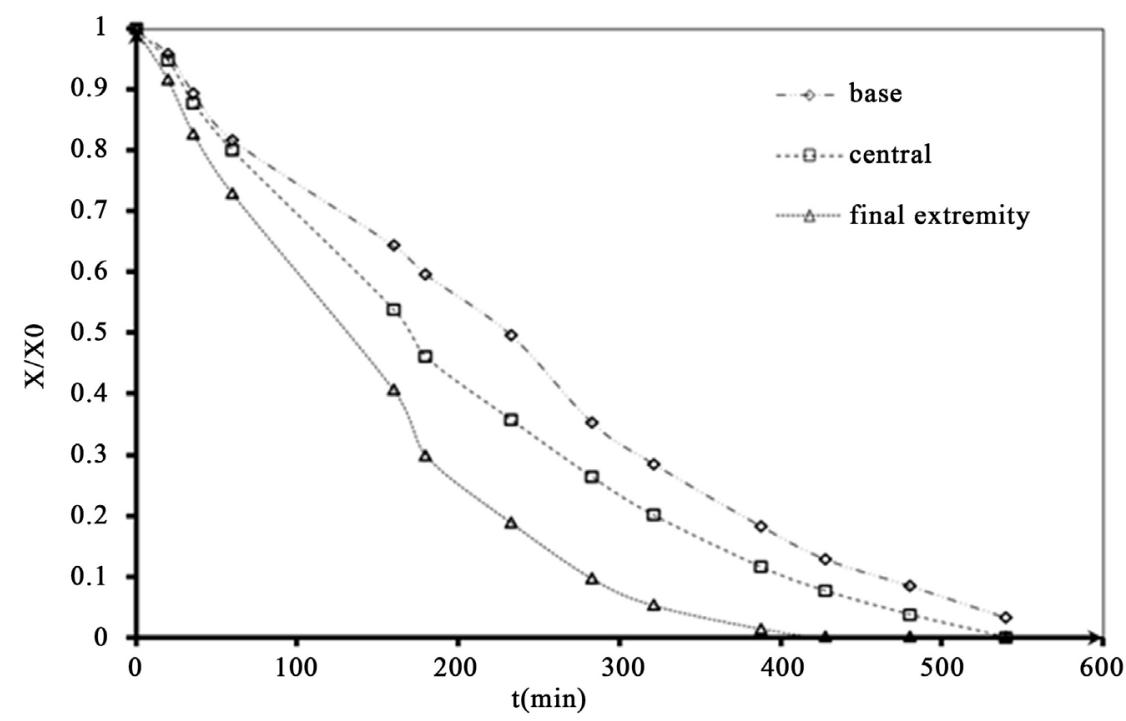

Figure 5. Okra longitudinal behaviour during convective drying, $70^{\circ} \mathrm{C}$. 


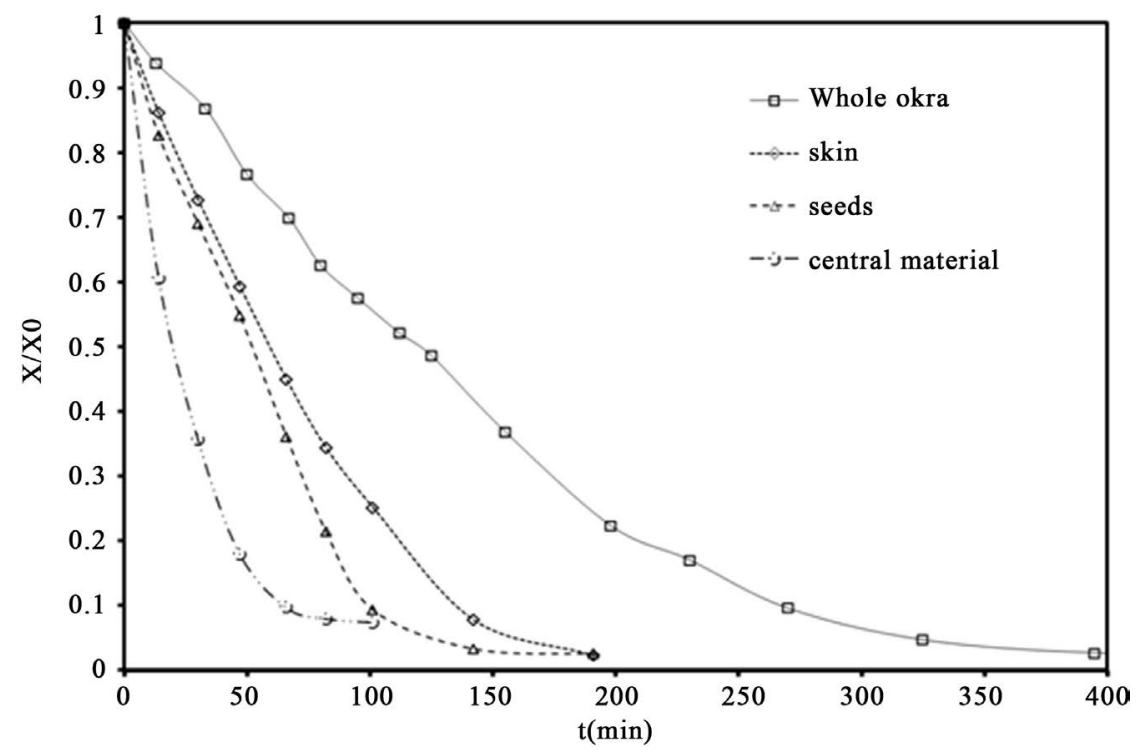

Figure 6. Contribution of okra constituents in the process of its convective drying.

\section{Conclusions}

In this work, various processes are used to optimize okra's convective drying. To achieve this objective, whole okra drying was studied by taking into account the state of maturity of the vegetable. Also, okra composition and mechanical appearance are well considered in the present work. We can notice that okra dries faster when it is too young or when advanced in age.

Drying samples were taken from all the length of the okra; we found that the different places of okra did not behave in the same ways during convective drying. The samples taken on the base, in the middle and at the end of the okra have respectively $400 \mathrm{~min}, 520 \mathrm{~min}$ and $600 \mathrm{~min}$ of drying time.

Cut made on okra before its convective drying has an influence on it and dries faster than the whole okra. The samples cut longitudinally, sliced in $5 \mathrm{~mm}$ and $10 \mathrm{~mm}$ of thickness and the whole okra takes respectively $150 \mathrm{~min}, 200 \mathrm{~min}, 280$ min and 400 min to dry. This work also shows that three components of okra, the central material, the seeds and the skin behave differently during convective drying. The drying time of these three components is $70 \mathrm{~min}, 150 \mathrm{~min}$ and 190 min respectively, against $400 \mathrm{~min}$ for the whole okra. Among these three constituents the skin is the one which slows down considerably the drying. So, it would be important to take into account the multi-constituent character of the okra during its drying. We could dry the okra by opening largely the skin. Indeed, opening the skin allows to avoid accumulation of steam in the okra which increases the pressure and also to renew the air inside the okra. Besides, the opening allows exhibiting the different constituents in the drying conditions and increasing air-produces exchange surface for efficient drying.

\section{Conflicts of Interest}

The authors declare no conflicts of interest regarding the publication of this paper. 


\section{References}

[1] Kordylas, J.M. (1991) Processing and Preservation of Tropical and Subtropical Foods. Macmillan Education Ltd., UK.

[2] Doymaz, I. (2007) Air-Drying Characteristics of Tomato. Journal of Food Engineering, 78, 1291-1297. https://doi.org/10.1016/j.jfoodeng.2005.12.047

[3] Camciuc, M., Deplagne, M., Vilarem, G. and Gaset, A. (1998) Okra Abelmoschus esculentus L. (Moench.) a Crop with Economic Potential for Set Aside Acreage in France. Industrial Crops and Products, 7, 257-264. https://doi.org/10.1016/S0926-6690(97)00056-3

[4] Avallonea, S., Tiemtorea, T.W.E., Rivierb, C. and Trècheb, S. (2008) Nutritional Value of Six Multi-Ingredient Sauces from Burkina Faso. Journal of Food Composition and Analysis, 21, 553-558. https://doi.org/10.1016/j.jfca.2008.04.012

[5] Sengkhamparn, N., Sagis, L.M.C, Renko de Vries, A., Henk Schols, H.A., Sajjaanantakul, T., Alphons, G.J. and Voragen, A.G.J. (2008) Physicochemical Properties of Pectins from Okra (Abelmoschus esculentus (L.) Moench). Food Hydrocolloids, 24, 35-41. https://doi.org/10.1016/j.foodhyd.2009.07.007

[6] Nadeau, J.P. and Puiggali, J.R. (1995) Séchage: des processus physiques aux procédés industriels. Tec \& Doc Lavoisier, Paris.

[7] Hassini, L., Azzouz, S., Peczalski, R. and Belghith, A. (2007) Estimation of Potato Moisture Diffusivity from Convective Drying Kinetics with Correction for Shrinkage. Journal of Food Engineering, 79, 47-56.

https://doi.org/10.1016/j.jfoodeng.2006.01.025

[8] Ouoba, K.H. (2013) Séchage des produits agroalimentaires : Influence de la taille, de la forme et de la découpe. Thèse de Doctorat, Université de Ouagadougou, Burkina Faso.

[9] Ouoba, K.H., Desmorieux, H., Zougmoré, F. and Naon, B. (2010) Caractérisation du séchage convectif du gombo, influence de la découpe et de ses constituants. Afrique Sciences, 6, 37-48.

[10] Dissa, A.O., Desmorieux, H., Savadogo, P.W., Segda, B.G. and Koulidiati, J. (2010) Shrinkage, Porosity and Density Behaviour during Convective Drying of Spirulina. Journal of Food Engineering, 97, 410-418. https://doi.org/10.1016/j.jfoodeng.2009.10.036

[11] Ouoba, K.H., Zougmoré, F., Sam, R., Toguyeni, A. and Desmorieux, H. (2014) Characterization of Okra Convective Drying, Influence of Maturity. Food and Nutrition Sciences, 5, 590-597. https://doi.org/10.4236/fns.2014.56069

[12] Wang, N. and Brennan, J.G. (1992) Effect of Water Binding on the Drying Behavior of Potato. Drying, 92, 1350-1359.

[13] Sablani, S., Rahman, S. and Al-Habsi, N. (2000) Moisture Diffusivity in Foods an Overview. In: Mujumdar, A.S., Ed., Drying Technology in Agriculture and Food Sciences, Science Publishers, Enfield, 35-59.

[14] Saravacos, G.D. and Maroulis, Z.B. (2001) Transport Properties of Foods. Marcel Dekker, New York.

[15] Hashemi, G., Mowla, D. and Kazemeini, M. (2009) Moisture Diffusivity and Shrinkage of Broad Beans during Bulk Dryin in an Inert Medium Fluidized Bed Dryer Assisted by Dielectric Heating. Journal of Food and Engineering, 92, 331-338. https://doi.org/10.1016/j.jfoodeng.2008.12.004

[16] Roberts, J.S., Tong, C.H. and Lund, D.B. (2002) Drying Kinetics and Time-Temperature Distribution of Pregelatinized Bread. Journal of Food Science, 67, 1080-1087. 
https://doi.org/10.1111/j.1365-2621.2002.tb09456.x

[17] Rizvi, S.S.H. (1986) Thermodynamic Properties of Foods in Dehydration. In: Rao, M.A. and Rizvi, S.S.H., Eds., Engineering Properties of Foods, Marcel Dekker Inc., New York, 133-214.

[18] Rovedo, C.O., Suarez, C. and Viollaz, P.E. (1995) Drying of Foods: Evaluation of a Drying Model. Journal of Food Engineering, 26, 1-12. https://doi.org/10.1016/0260-8774(94)00037-A

[19] Crank, J. (1975) The Mathematics of Diffusion Second. Oxford University Press, London, 69-88.

[20] Jason, A.C. (1958) A Study of Evaporation and Diffusion Processes in the Drying of Fish Muscle. In: Fundamental Aspects of Dehydration of Foodstuffs, Society of Chemical Industry, London, 103-135.

[21] Villa-Corrales, L., Flores-Prieto, J.J., Xamán-Villaseñor, J.P. and García-Hernández, E. (2010) Numerical and Experimental Analysis of Heat and Moisture Transfer during Drying of Ataulfo Mango. Journal of Food Engineering, 98, 198-206. https://doi.org/10.1016/j.jfoodeng.2009.12.026

[22] Doymaz, I. (2005) Drying Behaviour of Green Beans. Journal of Food Engineering, 69, 161-165. https://doi.org/10.1016/j.jfoodeng.2004.08.009 